\title{
Electoral Cycles in Government Policy Making: Strategic Timing of Austerity Reform Measures in Western Europe
}

\author{
Daniel Strobl ${ }^{1}$, Hanna Bäck², Wolfgang C. Müller ${ }^{1 \star}$ (D) and Mariyana Angelova ${ }^{1}$ \\ ${ }^{1}$ Department of Government, University of Vienna and ${ }^{2}$ Department of Political Science, Lund University \\ *Corresponding author. E-mail: wolfgang.mueller@univie.ac.at
}

(Received 20 October 2017; revised 20 November 2018; accepted 4 February 2019; first published online 8 November 2019)

\begin{abstract}
This article investigates whether governing parties strategically time austerity policies to help them win reelection. It contributes to existing research by focusing directly on government policy output, analyzing over 1,200 welfare and taxation austerity measures in thirteen Western European countries over twenty years. In line with previous research, the authors find that governments become less likely to introduce austerity measures as elections approach. The study introduces original hypotheses about which governments have the ability and opportunity to strategically time policy decisions. The authors suggest that minimal winning cabinets with leadership change (new prime ministers) face less complex bargaining environments and can credibly shift responsibility for austerity measures to the preceding government. The empirical analyses show that these governments are most likely to strategically time austerity policies.
\end{abstract}

Keywords: electoral cycles; austerity reforms; social policy; taxation policy; Western Europe

Political electoral cycles - the periodic occurrence of government policy decisions induced by the cyclicality of elections - have long been investigated as a strategic element of politics in modern democracies (for example, MacRae 1977; Nordhaus 1975). Given that voters punish or reward incumbents for their performance in office, parties can use the timing of reforms to influence their popularity before elections.

Austerity measures, which we define as policy changes that either cut welfare benefits or raise taxes (see, for example, Jordà and Taylor 2016; Martin and Philippon 2017), in particular should necessitate careful consideration by governments, especially since voters might be more sensitive to (monetary) losses than to gains (Weaver 1986, 373; see also Kahneman and Tversky 1986; Pacek and Radcliff 1995). Prior studies thus expect that governments strategically time austerity reforms according to the electoral cycle in order to maximize their chances of re-election (Hübscher and Sattler 2017). While recent research on voting behavior challenges the notion that welfare cuts are unconditionally damaging to parties in government (for example, Giger and Nelson 2011, 2013; Schumacher, Vis, and Van Kersbergen 2013), politicians demonstrably perceive austerity measures as politically risky and try to avoid accountability for their implementation (Klitgaard and Elmelund-Præstekær 2014; König and Wenzelburger 2017; Pierson 1996; Vis 2009; Weaver 1986; Wenzelburger 2014; Wenzelburger and Hörisch 2016). This manuscript contributes to the literature on political electoral cycles by investigating whether - and under what conditions - governments strategically time austerity measures for electoral benefit.

Given the central role of the economy for voting decisions (for example, Duch and Stevenson 2008), analyses of political cycles have been pioneered by the political business cycles literature, which suggests that governments boost the economy prior to elections in order to win additional

(c) Cambridge University Press 2019. This is an Open Access article, distributed under the terms of the Creative Commons Attribution licence (http://creativecommons.org/licenses/by/4.0/), which permits unrestricted re-use, distribution, and reproduction in any medium, provided the original work is properly cited. 
votes (MacRae 1977; Nordhaus 1975). However, this literature has been widely challenged on theoretical and empirical grounds and finds mixed support (for example, Alesina, Cohen, and Roubini 1993; Drazen 2001; Krause 2005). Weak or mixed findings might be largely due to the fact that scholars in this field typically investigate macro-economic outcomes such as GDP growth, inflation and unemployment rates (see, for example, Drazen 2001), which depend only partially on the decisions of national governments. Many scholars have therefore shifted their focus towards fiscal outcomes (for example, government spending), which are more directly under government control. Studies on fiscal outcomes provide a strong theoretical basis (for example, Blais and Nadeau 1992; Persson and Tabellini 2000; Prichard 2018; Rogoff and Sibert 1988) and empirical evidence for the existence of political budget cycles (see, for example, Alt and Lassen 2006; Chang 2008; Klomp and De Haan 2013; Mink and De Haan 2006; Shi and Svensson 2006). However, this line of research mainly focuses on policy outcomes rather than governments' direct policy decisions, which carries the risk that external factors rather than parties' choices drive some of the observed dynamics.

This article addresses the challenges of the cycles literature by completing the shift from policy outcomes to actual government policy decisions. In line with previous research, we argue that governments minimize the risk of alienating voters by strategically introducing austerity reforms earlier instead of late in the legislative cycle. The rationale for this behavior is not only that voters discount past events in favor of recent actions (Nordhaus 1975), but also that new governments have the opportunity to credibly shift responsibility for such measures to the previous incumbents and their heritage. According to this theoretical argument, we expect that the strategic timing of austerity measures should be more likely when there are major reshuffles in government leadership, like a change in prime minister in a newly formed government. We further suggest that not all governments are able to use the short window of opportunity to introduce austerity measures early on. We expect that governments facing less complex bargaining environments, such as minimal winning cabinets (as opposed to minority or oversized cabinets), are more effective at strategically timing austerity measures.

To evaluate our theoretical expectations, we analyze the timing of austerity measures and use a new and unique dataset with more than 1,200 important taxation and social policy reform measures introduced by governments in thirteen Western European countries between 1985 and 2005. To create this dataset, we coded more than 1,000 periodical country reports issued by the Economist Intelligence Unit (EIU) and the Organisation for Economic Co-operation and Development (OECD).

In line with past findings of the electoral cycles literature, our results show that governments are more likely to introduce and adopt austerity measures at the beginning of the legislative term. We find that minimal winning governments are more likely to strategically time austerity measures, especially when there is a change in the prime minister. Hence, the results support the theoretical argument that governments with less complex bargaining environments have the ability to act swiftly and use the short window of opportunity that results from a leadership change. Our results also lend support to the argument that governments use the opportunity to blame their predecessors for the country's current budgetary problems and credibly shift responsibility for the necessity of austerity measures to the previous government. These findings have important implications for our understanding of how governments in representative democracies structure their reform agenda and make strategic policy choices.

\section{The Literature on Electoral Cycles}

\section{Political Business and Budget Cycles}

The literature on political business cycles introduced the idea that governments seek to maximize their chances of re-election by strategically timing policies following the electoral cycle. Its 
starting point is the economic voting literature, which has shown that economic conditions (for example, growth, inflation and unemployment levels) play a central role in the electoral decisions of voters and the parties' electoral fortunes (for example, Duch and Stevenson 2008; Fiorina 1981; Lewis-Beck 1990; Powell and Whitten 1993). The seminal contributions by Nordhaus (1975) and MacRae (1977) hypothesized that governments manipulate the economy to ensure that economic conditions are good when they are up for re-election.

Despite some initial supporting evidence, political business cycle models have vanished for both theoretical reasons and due to a lack of (or mixed) empirical support in later empirical studies (for example, Alesina, Cohen and Roubini 1993; Krause 2005; McCallum 1978; for reviews see Drazen 2000; Drazen 2001, 228-46; Mueller 2003). One central reason for the weak empirical support is governments' limited control over economic outcomes, which is due, for instance, to the delegation of monetary policy to central banks and the growing influence of global markets (Clark et al. 1998; Hellwig and Samuels 2007). ${ }^{1}$

Considering these constraints, later research has focused on the impact of elections on fiscal decisions, which are under the direct control of governments (for example, Blais and Nadeau 1992; Franzese 2002; Persson and Tabellini 2000; Prichard 2018; Rogoff and Sibert 1988). ${ }^{2}$ The political budget cycle literature argues that governments improve their electoral prospects by adapting their spending behavior to the electoral cycle, and by distributing money among the electorate prior to elections (Drazen and Eslava 2010; Schultz 1995, for reviews see De Haan 2014; De Haan and Klomp 2013; Shi and Svensson 2006). An increase in welfare spending in the run-up to elections should not only boost the economy and directly benefit voters (for example, Bickers and Stein 1996; Kriner and Reeves 2012); it could also signal economic competence to voters (Rogoff and Sibert 1988), thereby increasing government popularity.

\section{Electoral Cycles and Legislation}

While fiscal policy directly relates to government decisions, external factors beyond the control of the cabinet can influence budget deficits and government spending. For example, higher unemployment rates can automatically increase government spending on unemployment benefits, and a growing elderly population leads to higher pension expenditures.

A more direct way to investigate the electoral opportunism of political parties is to focus directly on government policy decisions. Policies, as implemented through laws or decrees, provide voters with valuable information about governments' agendas, and send signals about their policy competence and efficiency, which voters are likely to take into account when they cast their vote. Additionally, the news media regularly cover important policy changes, such as austerity reforms, thus making them more visible to voters than budget figures.

Despite the fact that legislation is the core business of governments, current evidence on the existence of legislative electoral cycles is limited to a small number of studies providing mixed empirical support (for a review, see Kovats 2014). For instance, Shughart and Tollison (1985) argue that political manipulation of the macro-economy necessitates an increase in legislative output, yet their analysis finds no empirical correlation between macroeconomic indicators, elections and legislative outputs. By contrast, Lagona and Padovano (2008) report increases in legislative output in Italy shortly before elections.

\footnotetext{
${ }^{1}$ Another reason for the weak findings might be that instead of engaging in costly, hard to achieve and often distortionary macroeconomic manipulations, some governments can choose the timing of elections and call for early elections when the economy is beneficial for their electoral prospects (see, e.g., Heckelman and Berument 1998; Ito and Park 1988; Kayser 2005). In support of this suggestion, pre-electoral economic manipulation seems to be weak in countries that permit early elections (see, e.g., Ito 1990).

${ }^{2}$ Besides a strong focus on fiscal policy, the political budget cycles literature has also devoted considerable attention to the role of elections in monetary policy decisions and outcomes (see, e.g., Clark 2002; Clark and Hallerberg 2000; Hallerberg, de Souza, and Clark 2002).
} 
While these studies paved the way for research on legislative electoral cycles, their potential shortcoming is that they investigate all passed legislation, including incremental laws, which may not have a substantive impact on the economy (Willett and Bananian 1988). Furthermore, only substantive laws have a high likelihood of attracting media attention and reaching voters. Therefore, taking the mere quantity of formal legislation into account when investigating political cycles can result in misleading findings. To address this issue, Kovats (2014) analyses important legislative decisions of the European Union and provides some support for the idea that there is opportunistic timing of European legislation.

While the studies by Lagona and Padovano (2008) and Kovats (2014) concentrate on the volume of legislation, Hallerberg and Scartascini (2017) focus on the substance of laws and investigate tax changes in Latin America. In line with the political cycle literature's expectations, they find that tax increases are less likely in election years. Similarly, Stokes (1999) demonstrates that Latin American governments time austerity measures strategically after elections to avoid negative voter responses.

We contribute to this literature by investigating electoral cycles of reforms across Western European countries and over time; we focus on important legislation and take its content into account. Specifically, we concentrate on important austerity reform measures, introduced across thirteen West European countries over a period of twenty years. We extend the current understanding of electoral cycles of policy making by presenting original hypotheses suggesting that some governments are more likely to have the opportunity and ability to strategically time legislation. We present our theoretical expectations in the next section.

\section{Theoretical expectations on the timing of austerity measures}

In this section, we argue that governments follow a vote-seeking strategy and introduce austerity measures early on in the electoral term, banking on voters' recency bias and blurred lines of responsibility with the previous government. We theorize that such behavior is more likely when the prime minister is new and when the government is minimal winning (rather than oversized or minority) as these conditions allow governments to shift blame to predecessors and reach consensus on austerity measures quickly. We start by presenting the assumptions we make about parties and voters.

\section{Underlying Assumptions about Parties and Voters}

One of our core assumptions is that politicians are vote seeking: in order to increase their electoral chances, governments will try to send positive signals to voters and will avoid introducing policies that are costly for the voters in the run-up to elections. At the same time, governments operate within strict budgetary constraints. In order to achieve fiscal balance and to finance current and future public expenses, governments may need to introduce austerity measures at some point during their time in office. We also assume that political parties see austerity policies as a political risk (see, for example, Vis 2009; Wenzelburger and Hörisch 2016), and that politicians will engage in various blame avoidance strategies to avert drawing the ire of voters for such policies (see, for example, McGraw 1990; Weaver 1986).

Drawing on previous research, we assume that voters heavily discount the past and give greater weight to recent political accomplishments when they decide for whom to vote (see, for example, Healy and Lenz 2014). ${ }^{3}$ This 'recency bias' may arise due to two main reasons. First, voters may value recent events more because they are more informative and relevant for predicting future

\footnotetext{
${ }^{3}$ Literatures from various fields, such as political economy (Alesina et al. 1993; Fair 1978; Healy and Lenz 2014), research on electoral campaigns (Hill et al. 2013) and psychology (e.g., Schacter 1996), provide strong empirical support for the recency bias and the short memory of voters. Alesina et al. (1993), for example, report that the effect of current growth shocks
} 
actions and policy developments than distant events (MacKuen, Erikson and Stimson 1992). Secondly, it is easier to access and retrieve current information from memory. This cognitive bias leads voters to place more weight on the period right before elections when they evaluate the economic performance of incumbents (Healy and Lenz 2014).

Another important assumption that we make here is that voters are likely to pay attention to the introduction of austerity measures prior to their implementation. While some austerity measures can take considerable time until voters experience their monetary costs, we expect that voters evaluate current austerity measures when they are introduced and passed in parliament. The introduction of austerity measures in cabinet or parliament, and their later passage, can entail electoral costs for the government parties that introduced and passed them. This should even be the case for austerity measures for which an impact is not felt for decades, such as pension reforms. If an austerity measure increases the retirement age or lowers monthly pension payments, we expect that citizens punish the responsible government in the election immediately following the introduction and passage of a reform measure, rather than waiting for the legislation to take effect in the future. We therefore assume that voters will respond to information surrounding the introduction of austerity measures, which is also when policy changes are the focus of public debate and news media coverage. Governments should thus be careful in announcing and passing austerity measures, and we therefore expect them to time these policy signals opportunistically.

\section{Theoretical Expectations}

Our central argument is that parties in government strategically avoid introducing austerity measures late in the electoral cycle, that is, in the run-up to elections. We further argue that the extent to which governments will use this strategy depends on both the opportunity to shift responsibility to previous cabinets and the new cabinet's capacity for timely decision making and swift action. In the following sections, we elaborate on our theoretical arguments.

\section{Opportunistic Timing of Austerity Measures}

Austerity measures, such as increases in tax rates and public spending cuts, have an immediate adverse impact on the affected citizens by decreasing their expected and actual disposable income. While parties in government have incentives to avoid reforms that are likely to be negatively perceived by voters (such as austerity measures), they often need to introduce such reforms to achieve fiscal balance. Given governments' budgetary constraints, and voters' recency bias, strategically timing the same set of policy actions can minimize voters' alienation and maximize support. A government's risk of damaging its popularity becomes much more critical the closer the election date (see also König and Wenzelburger 2017). We therefore expect that governing parties will favor introducing austerity measures early in the legislative term, which allows negative signals to dissipate until the time of the election. In line with these considerations, our first hypothesis states that:

Hypothesis 1: Governments are more likely to introduce austerity measures early in the legislative term.

\section{Clarity of Responsibility and Opportunistic Timing of Austerity Measures}

In addition to voters' recency bias, governments also have an incentive to introduce austerity measures early on because of blurred lines of responsibility. Time spent in office is essential

on election results is two times stronger than the effect of lagged growth shocks. Fair (1978) finds considerably weaker economic voting for time frames more than one year prior to elections. 
here. We expect that the longer a government has been in office, and therefore the more time it has had to influence the policy agenda, the more likely it is that voters will hold it responsible for policy outcomes. At the beginning of the legislative term, governments inherit the policy status quo from the previous incumbent. We suggest that when there is a change in government leadership, a new government can credibly claim that unpopular measures are necessary to cope with the budgetary gap inherited from the previous government. The credibility of this claim fades the longer the new government is in office. In this way, new governments can credibly shift responsibility for the necessity of austerity measures to the preceding government. ${ }^{4}$ Due to blurred lines of responsibility between the current and previous governments at the beginning of the legislative term, it is less likely that austerity measures will negatively affect a new government when they are introduced early rather than late in the term. This reasoning is in line with the 'clarity of responsibility' literature, which suggests that incumbents are punished to a lesser extent in settings with blurred lines of responsibility (Powell and Whitten 1993).

We take a change in the prime minister as an indicator of a major change in government leadership (for example, Bunce 2014). While small changes in the party composition of the cabinet may not substantially shift public perceptions of government responsibility, new prime ministers can signify a major change in government policy direction, which enables the new government to shift responsibility for the inherited problems to its predecessor. Such a shift of responsibility is particularly straightforward when the new prime minister represents a different party than his or her predecessor, but it may also be credible when a politician from the same party replaces the prime minister (in the context of party leadership change). ${ }^{5}$ We suggest that both scenarios provide newly formed governments a viable opportunity to shift responsibility for austerity measures to the previous government. Our second hypothesis therefore says that:

Hypothesis 2: Governments with a new prime minister are more likely to introduce austerity measures early in the legislative term than those with a sitting prime minister.

\section{Government Type and Opportunistic Timing of Austerity Measures}

We also expect that some governments are better equipped to time their policy output strategically according to the electoral cycle. To take advantage of their chance to shift blame, newly formed governments need to act fast and decide on major austerity measures early in the legislative term. Governments have a short window of opportunity to secure a parliamentary majority willing to approve measures that impose direct costs on voters. This benefits governments that face less complex decision making in cabinet and parliament.

To capture the level of decision-making complexity that governments face when they make policy decisions, we propose focusing on government types: minority, minimal winning and oversized cabinets, where a minority cabinet does not control a majority of seats in the legislature, and an oversized cabinet includes at least one party that is not necessary for obtaining a legislative majority. This measure entails valuable information about the legislative majorities of the parties in government and captures internal bargaining dynamics that influence the government's ability to act swiftly and time legislation opportunistically. In addition, government type is a simple measure that is easy to operationalize and entails little measurement error. Our argument is, in short, that minimal winning cabinets face less complex bargaining than minority and oversized cabinets, and will thus be more able to expeditiously introduce austerity measures.

\footnotetext{
${ }^{4}$ Such responsibility shifts, or 'scapegoating', is one of the blame avoidance strategies identified by Weaver (1986).

${ }^{5}$ In more general terms, new leaders from the same party can reverse key policy decisions of their predecessors to distinguish party from leader accountability (e.g., John Major's scrapping of Margaret Thatcher's poll tax) or visibly change course (such as the new generation of more market-oriented Social Democratic leaders taking over in the 1990s; Maravall 1997), without being held accountable for their predecessors' policies.
} 
As minority governments do not hold a parliamentary majority, they need to secure the support of opposition parties. Opposition parties might be willing to support the government and agree to reform policies when these are directly beneficial to them and their electorate. However, austerity measures impose direct costs on voters without a clear direct benefit for opposition parties. Government parties need austerity measures to consolidate the budget, to cover the running costs and to pay for their own new policies. Yet opposition parties may have more to gain from the failure of the government strategy as this limits the government's room to maneuver and perhaps leads to its fall. Opposition parties therefore might be willing to support austerity policies when they face poor options for government participation in the case of cabinet termination or uncomfortable electoral prospects in the case of early elections. If this is not the case, opposition parties are in a strong bargaining position vis-à-vis the government. We therefore expect that even centrally located minority cabinets that can juggle between opposition parties and play them off against each other (Crombez 1996; Laver and Schofield 1998) will have difficulty securing the support of opposition parties for austerity measures without delay, and will have higher bargaining costs if they succeed. Accordingly, minority cabinets may be unable to pass austerity measures within the short window of opportunity at the beginning of the legislative term.

We suggest that while surplus parties in oversized coalitions can help sustain the coalition logrolls, thus enabling the cabinet to pass many bills successfully throughout the legislative term (see Carrubba and Volden 2000), such 'superfluous' parties are also likely to delay the introduction and passage of costly bills (for example, austerity measures) early in the legislative term.

Despite the fact that surplus parties are not necessary to pass a bill in oversized coalitions, ignoring their wishes comes with certain costs that governments should try to avoid, especially in the case of costly policies such as austerity measures. When government parties decide whether to ignore the wishes of the surplus party, they weigh the expected costs of doing so against the expected costs of making policy concessions to accommodate the policy demands of the surplus party. If it is more (less) costly to ignore the surplus party than agreeing to policy concessions that benefit the surplus party, then government parties will choose to respect (ignore) the surplus party's policy preferences. Ignoring this party's preferences induces some fixed reputation costs and variable opportunity costs.

Specifically, if government parties ignore the demands of a surplus party, this can hamper their reputation of being trustworthy coalition partners with current and potential future coalition partners. Having such a poor reputation will decrease their expected benefits from future logrolls, as they might have to coalesce with less desirable partners.

With respect to opportunity costs, introducing austerity measures against the wishes of a government partner raises doubt regarding the necessity of these measures, which in turn lowers their legitimacy and increases audience costs. In addition, by excluding the surplus party from coalition decisions, government parties bypass the chance of gathering broad support and dispersing the responsibility for costly measures among all government parties.

We suggest that parties' incentives to avoid costly intra-cabinet conflict related to austerity measures and to divide the responsibility among all coalition partners should be stronger the higher the costs a bill imposes on voters. For very costly bills, such as austerity reform measures, government parties should clearly benefit from the support of the surplus cabinet parties, as this increases the legitimacy of the bill and blurs the lines of responsibility between the governing parties. Both of these consequences should reduce the electoral losses that are likely to arise from introducing austerity measures for each of the government parties.

Why should this delay the introduction of austerity reforms? While coalition partners need the support of surplus parties for costly reforms such as austerity measures, they need surplus parties to a lesser extent for less costly policy measures and thus may ignore their demands. Given that governments have incentives to pass reforms that impose costs on voters early in the legislative term and thus need surplus parties more strongly early on, surplus parties face uncertainty 
regarding whether they can get their desired bills passed later. Surplus parties will therefore seek to ensure that coalition partners need their support throughout the entire legislative period. This gives them incentives to delay and disperse the introduction of austerity measures throughout the legislative term. They can do so by threatening to oppose costly measures and hence reduce these measures' legitimacy and increase audience costs. By delaying the passage of austerity measures, surplus parties can keep the costs of ignoring them high and bargain to pass their desired policies early on. The other government parties, in turn, are likely to accept the demands of surplus parties in order to increase the legitimacy of their austerity measures and blur the lines of responsibility.

In contrast, in minimal winning coalitions, no party can be ignored, and all government parties will have strong incentives to introduce austerity measures early in the legislative term. The decision-making processes in oversized governments are thus more complex, and may considerably delay the passage of legislation. Hence, it will take longer for parties in oversized cabinets to agree on controversial and costly reform measures; such cabinets should thus be less able to introduce austerity measures early in the legislative cycle.

Given the above considerations, we expect that minimal winning governments are better equipped to strategically time austerity measures to their needs compared to minority and oversized governments, and we thus hypothesize that:

Hypothesis 3: Minimal winning governments are more likely than minority and oversized governments to introduce austerity measures early in the legislative term.

Lastly, we expect that the impact of both factors is conditional on the other. That is, the opportunity to shift responsibility for austerity measures to the previous government should result in the strategic timing of austerity measures when governments can act swiftly. Accordingly, we expect that minimal winning cabinets with a new prime minister are most likely to time austerity measures strategically. In such cabinets, parties can credibly shift responsibility to the previous government and face minimal bargaining complexity, which allows them to use the short window of opportunity to introduce austerity measures early on. Conversely, cabinets that have neither the possibility to shift blame (that is, when there is no change in leadership) nor a bargaining environment that expedites decision making should be less effective at timing austerity measures strategically. We thus hypothesize that:

Hypothesis 4: Minimal winning governments with a new prime minister are more likely than oversized and minority governments with a sitting prime minister to introduce austerity measures early in the legislative term.

\section{Data and Methods}

\section{A New Dataset on Reform Measures in Thirteen Western European Countries Over 20 Years}

We evaluate our hypotheses using data on substantive social and taxation reform measures introduced in thirteen Western European countries for a period of twenty years (ca. 1985-2005, covering the entire office periods of the cabinets beginning or ending closest to these dates). Our sample includes data from eighty-nine cabinets in Austria, Belgium, Denmark, Finland, France, Germany, Ireland, Italy, Netherlands, Portugal, Spain, Sweden and the United Kingdom. These countries were either part of the European Common Market for the entire observation period or acceded in 1995 (Austria, Finland and Sweden). The selection of Western European countries ensures that the broader economic framework conditions are comparable across all countries.

While previous analyses of electoral cycles predominantly focus on policy outcomes and economic indicators that are only partially under the control of the government - such as GDP 
growth or spending and deficit levels - we analyze governments' direct policy decisions. For this purpose, we manually coded more than 1,000 periodical country reports issued every three months (every month after 2007) by the EIU and country reports issued annually or biannually by the OECD.

The leading goal of EIU reports is to inform business investors, international organizations and government agencies about the current policy situation and concrete policy changes invoked by the government in a given country. The EIU reports provide information on relevant reform measures introduced via laws or government decrees that change the policy status quo; they do not report merely incremental provisions. In terms of coverage of Western countries and time frequency, breadth and detail of reporting on economic and social policy developments, these sources are unmatched. Designated country experts prepare reports on socio-economic policy making using various information channels such as official statements, media reports and direct contact with government officials. The reporting follows common guidelines and is closely monitored by the EIU's central editorial team, which allows for cross-country comparisons. To crossvalidate the EIU country reports' coverage we also coded more than 200 OECD country reports. Whenever the OECD Economic Surveys mention additional information on reform measures omitted from the EIU reports, we included these measures in our database.

We follow an extensive coding scheme to extract all socio-economic reform measures mentioned in the EIU and OECD country reports. ${ }^{6}$ We coded every reform measure individually, even if it occurred in a package with other measures, which allows for comparability across cases. Further, we code only concrete reform measures, indicating the policy instrument used to change the policy status quo. For example, the April 1990 EIU report on Sweden includes information on recent policy changes:

With the second Carlsson administration now in place and the new finance minister, Allan Larsson, promising to pursue market-oriented policies like his predecessor, Kjell-Olof Feldt, the Social Democrats again had to look for parliamentary support for their economic policy. [...] A deal was therefore hammered out, and was confirmed in Parliament on April 25. Its main features include... (EIU 1990, 10).

The report then lists a number of measures introduced as part of the policy package, in particular two austerity measures that increase the consumption taxes and social security contributions of employees:

- an increase in VAT of one and a half percentage points to 25 per cent as of July 1 this year. $[\ldots]$

- an increase in wage earners' unemployment contributions from 5 per cent to 10 per cent (EIU 1990, 10).

After identifying a relevant policy change from the original reports, we capture the available information for each reform measure in a number of variables. We code information on the dates of policy changes at four different stages: cabinet decision, bill brought into parliament, law enactment and legislation coming into force. We coded the timing of a reform measure at each stage for which the reports explicitly indicated the date; however, for some reform measures we do not have information about the dates of all stages. Hence, focusing only on one stage would result in

\footnotetext{
${ }^{6}$ The coding of reform measures using economic country reports, as with any other data-generating process, is associated with potential measurement error and the reports may miss some austerity measures that were introduced by governments. Due to the reports' stated policy of delivering comprehensive reporting on the most salient issues in a given country, we believe only minor policy changes are likely to be omitted. As such, potentially missing austerity measures should have a marginal impact on voters and on the reputation of government parties.
} 
missing cases of austerity measures. We focus on all cases and adopt a standardized coding whereby we choose the date of an austerity measure based on the best available information. Governments send voters a strong signal about their policy decisions when parliaments enact a law, which finalizes the policy decision. We therefore use the date of a law's enactment in parliament as the primary date of the reform measure. Announcements of cabinet decisions and bringing a bill for deliberation in parliament are also stages when governments send a strong signal and to which the news media devote considerable attention. Accordingly, where the enactment date was not available, we use the date when the draft bill was brought before parliament. Whenever this information was not available, we use the date of the cabinet decision or the date when a measure came into force. ${ }^{7}$

Aside from descriptive information, such as the date when a reform measure was introduced, we also capture the content of the reform measures in three policy variables with increasing levels of precision. At the most general level, we assigned each reform measure to one of four broad policy areas: social, taxation, labor market or economic policy. To identify austerity measures, we focus on social and taxation policy. We classified each measure from these policy areas into fourteen categories and twenty-two sub-categories, which allows us to capture the direction of a given reform measure (for example, higher corporate taxes, lower pension rates) (see Appendix Table A1). The first example from above, 'an increase in VAT', was assigned to taxation policy, under the category 'consumption taxes' and the sub-category 'increase of tax rate'. The second example, 'an increase in wage earners' unemployment contributions' was assigned to social policy, under the category 'unemployment' and the sub-category 'insured's fees/contributions up'.

In the following analysis, we use the information about the direction of the reform measures to classify the coded social and taxation reform measures into 'austerity' measures (see Table 1). We generally classify tax increases and spending cuts as austerity measures. These measures have a positive effect on the fiscal balance, as they bring in tax revenue and reduce budget outlays but impose direct costs on voters.

\section{Dependent and Independent Variables}

We structure our dataset into monthly units and analyze the probability that a cabinet will introduce austerity reform measures in a given month. Using the database on austerity reform measures described above, we code the dependent variable as a dichotomous variable that indicates whether one or more austerity measures were introduced in a given month $(0=$ no, $1=$ yes). All technical information on cabinets (start and end dates of the legislative term, party composition, government type, prime minister, etc.) was gathered using the Comparative Parliamentary Democracy Data Archive (Strøm, Müller and Bergman 2008) in combination with the ParlGov database (Döring and Manow 2016).

Our main explanatory variable is the percentage of time remaining in the legislative term (TIME). We calculate this variable as the number of months until the next scheduled election, divided by the maximum number of months in a regular legislative term (for example, forty-eight months in countries with a regular four-year legislative term). ${ }^{8}$ We start our count from the election month, which we gather from the ParlGov database (Döring and Manow 2016). ${ }^{9}$ For instance, the variable has a value of 100 per cent for those observations (=months) for which

\footnotetext{
${ }^{7}$ The variation in the availability of dates at various stages of the legislative process poses a potential issue for the validity of our empirical analyses. We provide robustness checks with a discussion in the Appendix (see Table A7 and Figure A1).

${ }^{8} \mathrm{We}$ run robustness tests for all our models in which we instead calculate the percentage of time remaining until the next actual election as our main explanatory variable. We find substantively similar results and present these in Table A8 and Figure A2 in the Appendix.

${ }^{9}$ We find slightly stronger effects when we exclude the election months (when parties are busy forming the government) from the analyses.
} 
Table 1. Classification of policy measures as austerity reform measures

\begin{tabular}{ll}
\hline Social policy & \multicolumn{1}{c}{ Taxation policy } \\
\hline Insured's fees/contributions up & $\begin{array}{l}\text { Increase of tax rate } \\
\text { Employer contributions up }\end{array}$ \\
$\begin{array}{l}\text { Creation of taxes } \\
\text { Benefits/services down }\end{array}$ & Tax allowances: overall effect decrease \\
Reduce beneficiaries/tighten eligibility criteria & \\
Limit benefit growth & \\
$\mathrm{N}=496$ & $\mathrm{~N}=756$ \\
\hline
\end{tabular}

Note: Observations refer to the number of individual measures that were coded from the country reports.

an election took place and a new legislative term started, and a value of 50 per cent when half of the legislative term has passed (twenty-four months in a four-year term or thirty months in a five-year legislative term).

All models include a control variable that indicates whether there was an economic crisis at the beginning of the cabinet term (CRISIS). This modeling choice is guided by Hallerberg and Scartascini (2017), who suggest that governments introduce reforms that increase revenues when they most need it, for example during crisis situations. At the same time, following the economic voting literature (see Duch and Stevenson 2008), the probability of a change in the government may increase during crises because voters are dissatisfied with the economy. To account for this potential confounding factor, we generate a dummy variable based on three economic indicators from the Comparative Political Data Set (Armingeon et al. 2015): the level of unemployment, the gross domestic product (GDP), and debt in the year when the government was formed. We code the variable as 1 when any of the following conditions occurs: unemployment levels are high (larger than 11.6 per cent, thus greater than the sample mean plus one standard deviation); the change in the GDP is negative; or debt levels are high (higher than the sample mean plus one standard deviation) (for a similar operationalization of economic crises, see Wiese 2014). We interact the crisis variable with our TIME variable as electoral cycles of austerity measures might be more pronounced during crises. The substantive effects in all models are robust to the exclusion of this interaction effect between the time left in the legislative term and the CRISIS variable.

As austerity measures are often introduced alongside other policy measures, we include a count of the number of other social and taxation measures introduced in the same months that are not classified as austerity measures according to our coding scheme (NONAUSTERITY). This serves as a strong test of our hypotheses, as it controls for all general decreases and increases in reform activity that are not related to substantive austerity measures. For instance, it may well be the case that governments are generally less active at the end of the legislative cycle as the parties in government focus on election campaigning.

We include yearly lags of three macroeconomic control variables to account for changes in the unemployment rate, GDP and the national debt (Armingeon et al. 2015). These controls vary by year. For instance, all twelve monthly observations in 1995 in a given country have the same value for UNEMP, which is the change in the unemployment rate from 1993 to 1994.

The variable SPELLS indicates the months passed since the last austerity measure and accounts for potential temporal dependence in the introduction of policy measures (Beck, Katz and Tucker 1998). We follow the recommendation by Carter and Signorino (2010) and include both a squared and cubed transformation of this variable. The results we report exhibit no sensitivity to the inclusion of these variables and are robust to alternative transformations (for example, natural cubic splines, see Beck, Katz and Tucker 1998).

In order to evaluate Hypotheses 2-4, we interact our time variable with two cabinet-level dummy variables indicating a change in prime minister (NEWPM) (Model 3) and whether the 
cabinet is minimal winning or not $(M W C)$ (Model 4). The variable NEWPM indicates a leadership change, which we capture with a change in the person who holds the prime minister post. This approach allows us to capture two possible scenarios: (1) a change in the party that holds the prime minister post and (2) a change in the cabinet leadership within the same prime minister party. The variable $M W C$ is a dummy variable for government type. It takes a value of 1 for minimal winning cabinets and 0 for oversized coalitions or minority cabinets. ${ }^{10} \mathrm{We}$ code prime minister change and government type using information provided by ParlGov (Döring and Manow 2016). Each of the government type categories has a reasonably large number of cases: forty-four minimal winning governments (sixteen of which are with a new prime minister) and forty-five minority and oversized governments (twenty-seven of which are with a new prime minister).

In the Appendix, we test the robustness of our findings using the minimal winning dummy variable to other measures of the bargaining environment of cabinets, such as the number of institutional and partisan veto players and their ideological distance. While these measures are related, we argue that distinguishing between government types is the most straightforward approach to testing our theoretical argument. For instance, the operationalization of veto players and their ideological conflict (measured as the ideological range between veto players) is complicated by the distinction between institutional veto players (legislative chambers, presidents, courts) and partisan veto players (government parties). Tsebelis (1995) has argued that while the agreement of institutional veto players is necessary for policy change, 'the agreement of partisan veto players is, strictly speaking, neither necessary nor sufficient' (Tsebelis 1995, 302, emphasis in original). In particular, in oversized cabinets at least one government party is not necessary for a majority and can be bypassed. In minority governments, the partisan veto players are not sufficient to pass a bill and need the support of the opposition, which might block the government for vote and office-seeking reasons (Ganghof and Bräuninger 2006). Given that the majority in parliament ultimately decides the fate of a bill, it is particularly difficult in the case of minority and oversized cabinets to identify which parties are veto players and necessary and sufficient for policy change. ${ }^{11}$ We report the descriptive statistics for all variables in Table 2.

\section{Statistical Model}

We model the dichotomous dependent variable (the introduction of an austerity reform measure) using logistic regression models with unconditional fixed effects at the cabinet level. We include dummy variables for each cabinet, which account for unobserved heterogeneity between cabinets. The fixed-effects model controls for all factors that vary between cabinets, such as the cabinet's ideological position, or the number of parties in government. This is important, as specific types of governments will be more likely to introduce austerity reform measures and these factors may correlate with our explanatory variables.

While the dummy variable approach to fixed-effects logit regression results in biased coefficient estimates when $t$ is small (for example, Greene 2004; Katz 2001), it produces estimates

\footnotetext{
${ }^{10}$ We replicate the analyses from Models 3 and 5 with a government type variable consisting of three categories: minority, minimal winning and oversized. We report the regression results in Table A4 (see Models A11 and A12) and substantive effects (predicted probabilities) for each cabinet type in Appendix Table A5.

${ }^{11} \mathrm{We}$ run robustness checks with other factors that can influence the policy-making process and can capture governments' ability to make policies (results reported in the Appendix). We consider the following factors - single vs. multiparty governments, minority vs. majority status of governments, checks and balances, number of government parties and left-right range in the government - as controls to government type and in separate models (see Tables A2 and A3). The effect of government type holds when we include these measures as controls (see Models A1-A5). Our separate models, which replicate Model 5 using the above factors instead of government type (see Models A6-A10), reveal that most of these factors have an effect in the expected direction. However, none of the three-way interactions are statistically significant (for more information, see the substantive results reported in Table A5 and our discussion in the Appendix).
} 
Table 2. Descriptive statistics

\begin{tabular}{|c|c|c|c|c|c|}
\hline & Mean & S.D. & Min. & Median & Max. \\
\hline \multicolumn{6}{|l|}{ Monthly variables (countries $\times$ months; $n=3,296$ ) } \\
\hline Austerity reform measures $(0 / 1)$ & 0.18 & 0.38 & 0.00 & 0.00 & 1.00 \\
\hline Percentage of time remaining in the legislative term & 55.21 & 27.15 & 0.00 & 55.67 & 100.00 \\
\hline Sum of other reform measures & 0.63 & 1.57 & 0.00 & 0.00 & 19.00 \\
\hline Months since the last austerity measure & 4.02 & 4.53 & 0.00 & 3.00 & 30.00 \\
\hline \multicolumn{6}{|l|}{ Yearly variables (countries $\times$ months; $n=286$ ) } \\
\hline$\Delta$ Unemployment rate (yearly lag) & -0.06 & 1.01 & -2.80 & -0.10 & 5.10 \\
\hline$\Delta$ GDP growth (yearly lag) & 2.77 & 2.13 & -5.91 & 2.69 & 11.27 \\
\hline$\Delta$ Debt (yearly lag) & 0.16 & 4.63 & -15.35 & 0.07 & 19.35 \\
\hline \multicolumn{6}{|l|}{ Cabinet-level variables $(n=89)$} \\
\hline Crisis at cabinet formation $(0 / 1)$ & 0.19 & 0.40 & 0.00 & 0.00 & 1.00 \\
\hline New prime minister $(0 / 1)$ & 0.44 & 0.50 & 0.00 & 0.00 & 1.00 \\
\hline Minimal winning cabinet $(0 / 1)$ & 0.53 & 0.50 & 0.00 & 0.00 & 1.00 \\
\hline
\end{tabular}

Note: Descriptive statistics for all variables are reported based on the final dataset used in the regression analyses (countries $\times$ months; $n=3,296)$.

for the fixed effects and intercepts. This allows us to calculate meaningful partial effects and predicted probabilities. We believe that the potential bias arising from the dummy variable approach is small for our analyses, as we have a sufficiently large amount of $t$ (=months) for each $n$ (=cabinet) (see discussion in Katz 2001). ${ }^{12}$ We further restrict our analysis to cabinets that were in office for at least one year $(t \geq 12)$. Seventy-nine of the eighty-nine cabinets in our final sample have at least twenty monthly observations.

We model the probability $p$ that cabinet $i$ introduces an austerity measure during a given month $t$ (see Models 1-5 in Table 3). We can express Model 1, which tests our first hypothesis, accordingly:

$$
\begin{aligned}
\log \left(\frac{p_{\text {it }}}{1-p_{\text {it }}}\right)= & \gamma_{0}+\alpha_{\mathrm{i}}+\beta_{1} \times \text { TIME }_{\mathrm{it}}+\gamma_{1} \times \mathrm{TIME}_{\mathrm{it}} \times \mathrm{CRISIS}_{\mathrm{i}} \\
& +\gamma_{2} \times \text { NONAUSTERITY }_{\mathrm{it}}+\gamma_{3} \times \Delta \mathrm{UNEMP}_{\mathrm{it}} \\
& +\gamma_{4} \times \Delta \mathrm{GDP}_{\mathrm{it}}+\gamma_{5} \times \Delta \mathrm{DEPT}_{\mathrm{it}}+\gamma_{6} \times \text { SPELLS }_{\mathrm{it}}+\gamma_{7} \times \text { SPELLS }_{\mathrm{it}}^{2} \\
& +\gamma_{8} \times \mathrm{SPELLS}_{\mathrm{it}}^{3}
\end{aligned}
$$

Models 1-5 include intercepts $\left(\gamma_{0}\right)$, cabinet dummies $\left(\alpha_{i}\right)$, the explanatory variable TIME $E_{i t}$ (percentage of time remaining in the legislative term) and the same set of control variables (with parameters $\gamma_{1}, \ldots, \gamma_{8}$ ) (for more information on the specific measures of each variable, see the previous section on the dependent and independent variables).

In addition, Model 2 includes the squared term of our main explanatory variable - time remaining in the legislative term, which tests for potential curvilinearity in this effect. Models 3, 4 and 5 also include dummy variables for a new prime minister $\left(N E W P M_{i}\right)$ and minimal winning cabinets $\left(M W C_{i}\right)$ separately (Models 3 and 4) and together (Model 5). Models 3-5 analyze whether cabinets with new prime ministers (Hypothesis 2), minimal winning governments (Hypothesis 3) and minimal winning government with new prime ministers (Hypothesis 4) are more likely to time austerity measures strategically. Due to the inclusion of cabinet fixed effects, the main effects of $N E W P M_{i}$ and $M W C_{i}$, which are constant at the cabinet level, drop out of the models. Instead, these variables are only included as an interaction with our main explanatory variable, which measures the percentage of time remaining in the legislative term.

\footnotetext{
${ }^{12}$ We replicate our main analyses using the conditional logit specification, which produces substantively identical results (see Appendix Table A6).
} 
Table 3. Regression estimates for the introduction of austerity reform measures

\begin{tabular}{|c|c|c|c|c|c|}
\hline & $\begin{array}{l}\text { Model } 1 \\
\text { Linear }\end{array}$ & $\begin{array}{l}\text { Model } 2 \\
\text { Curvi-linear }\end{array}$ & $\begin{array}{l}\text { Model } 3 \\
\text { New PM }\end{array}$ & $\begin{array}{c}\text { Model } 4 \\
\text { Cabinet type }\end{array}$ & $\begin{array}{c}\text { Model } 5 \\
\text { New } \mathrm{PM}^{\star} \text { Cab. type }\end{array}$ \\
\hline Time remaining in legislative term (\%) & $1.009^{\star \star \star}(0.002)$ & $1.040^{\star \star \star}(0.010)$ & $1.007^{\star}(0.003)$ & $1.005(0.004)$ & $1.008(0.005)$ \\
\hline Time remaining in legislative term (squared) & & $0.99973^{\star *}(0.00009)$ & & & \\
\hline $\begin{array}{l}\text { Time remaining in leg. term* } \\
\text { New prime minister (New } P M \text { ) }\end{array}$ & & & $1.004(0.005)$ & & $0.994(0.007)$ \\
\hline $\begin{array}{l}\text { Time remaining in leg. term } \\
\text { Minimal winning cabinet }(M W C)\end{array}$ & & & & $1.006(0.005)$ & $0.999(0.006)$ \\
\hline $\begin{array}{l}\text { Time remaining in leg. term* } \\
\text { New } \mathrm{PM}^{\star} \mathrm{MWC} \\
\text { Control variables }\end{array}$ & & & & & $1.022^{\star}(0.010)$ \\
\hline $\begin{array}{l}\text { Time remaining in leg. term* } \\
\text { Crisis at cabinet formation }\end{array}$ & $1.006(0.006)$ & $1.007(0.006)$ & $1.005(0.006)$ & $1.006(0.006)$ & $1.006(0.006)$ \\
\hline$\Delta$ Unemployment rate (yearly lag) & $0.901(0.093)$ & $0.900(0.095)$ & $0.900(0.093)$ & $0.887(0.093)$ & $0.881(0.092)$ \\
\hline$\triangle \mathrm{GDP}$ growth (yearly lag) & $0.972(0.054)$ & $0.952(0.054)$ & $0.973(0.055)$ & $0.962(0.054)$ & $0.955(0.054)$ \\
\hline$\Delta$ Debt (yearly lag) & $1.054^{\star \star}(0.020)$ & $1.052^{\star \star}(0.020)$ & $1.055^{\star *}(0.020)$ & $1.054^{\star \star}(0.020)$ & $1.052^{\star \star}(0.020)$ \\
\hline Sum of other reform measures & $2.021^{\star \star \star}(0.080)$ & $2.017^{\star \star \star}(0.080)$ & $2.023^{\star * *}(0.081)$ & $2.022^{\star \star \star}(0.080)$ & $2.027^{\star \star \star}(0.081)$ \\
\hline Constant & $0.059^{\star \star \star}(0.039)$ & $0.037^{\star \star \star}(0.026)$ & $0.051^{\star * *}(0.035)$ & $0.077^{\star \star \star}(0.053)$ & $0.091^{\star \star *}(0.065)$ \\
\hline Observations & 3,296 & 3,296 & 3,296 & 3,296 & 3,296 \\
\hline Log likelihood & $-1,208$ & $-1,203$ & $-1,208$ & $-1,207$ & $-1,204$ \\
\hline AIC & 2,613 & 2,604 & 2,614 & 2,613 & 2,610 \\
\hline
\end{tabular}

Note: Exponentiated coefficients from logistic regression analyses estimated in Stata 15 with unconditional fixed effects at the cabinet level; approximations for standard errors of the odds ratios in parentheses). The dependent variables indicate whether the government introduced an austerity measure during a given month or not (0/1). All models include a variable measuring the months since the last austerity measure, along with a squared and cubed transformation to account for temporal dependence following Carter and Signorino (2010; see methodology section for details) and dummy variables at the cabinet level (not reported). ${ }^{*} p<0.05,{ }^{* \star} p<0.01,{ }^{\star * \star} p<0.001$ 
Model 5 tests Hypothesis 4 and includes a three-way interaction among the dummy variables for new prime ministers and government type with our primary explanatory variable (percentage of time remaining in the legislative term). The model can therefore be written as follows:

$$
\begin{aligned}
\log \left(\frac{p_{\text {it }}}{1-p_{\text {it }}}\right)= & \alpha_{\mathrm{i}}+\boldsymbol{\gamma} \mathbf{X}+\beta_{1} \times \mathrm{TIME}_{\mathrm{it}}+\beta_{2} \times \mathrm{TIME}_{\mathrm{it}} \times \mathrm{NEWPM}_{i} \\
& +\beta_{3} \times \mathrm{TIME}_{\mathrm{it}} \times \mathrm{MWC}_{i}+\beta_{4} \times \mathrm{TIME}_{\mathrm{it}} \times \mathrm{NEWPM}_{i} \times \mathrm{MWC}_{i}
\end{aligned}
$$

\section{Empirical Analysis}

\section{Descriptive Results on the Timing of Austerity Measures}

To test the occurrence of electoral cycles of policy making, we analyze the relationship between the time remaining in the legislative term and the introduction of austerity measures. We first show the bivariate relationship between time and the introduction of austerity policy changes in Figure 1, which depicts the average number of policy measures across all cabinets during a given month after an election.

For each month after the last election, we calculate the mean of the raw number of austerity reform measures over the entire sample. For instance, cabinets introduced on average approximately 0.39 austerity measures thirty-six months after the last election. We plot the distribution of our main explanatory variable measuring the percentage of time remaining in the legislative term against the average number of austerity reform measures by month. The scatterplot reveals that the average number of austerity measures that cabinets introduce increases immediately after an election and then decreases steadily towards the next election. This pattern is in line with the hypothesized cycle of austerity measures, suggesting that the probability that governments will introduce such measures decreases as elections approach (Hypothesis 1).

\section{Multivariate Results on the Timing of Austerity Measures}

We proceed with a multivariate analysis of the relationship between the time until the next scheduled election in a country and the introduction of austerity policy measures. We present the results from our fixed-effects logistic regression models in Table 3. Models 1 and 2 test Hypothesis 1. We report the exponentiated coefficients (odds ratios) of the logistic regression models alongside an approximation of the standard errors of the odds ratios as reported by Stata. ${ }^{13}$ The exponentiated coefficient should be higher than 1 for Hypothesis 1 to be supported.

Model 1 reveals that an increase in our main explanatory variable (percentage of time remaining in the legislative term) increases the probability that governments will introduce austerity measures. This means that governments become less likely to introduce tax increases or cutbacks in social benefits as legislative elections draw nearer. We include the squared term of our main explanatory variable (percentage of time remaining in the legislative term) in Model 2, which allows us to test for potential curvilinearity in this effect (as revealed by the bivariate plot in Figure 1). The higher log-likelihood and the lower AIC of the second model both indicate that the curvilinear model fits the data better than the linear model.

A substantive representation of our results is provided in Figure 2, where we plot the predicted probabilities with 95 per cent confidence intervals of austerity reform measures from the beginning of the legislative term ( 100 per cent of time remaining) to the end of the term ( 0 per cent of time remaining). In line with Hypothesis 1, we find a sharp decrease in the predicted probability of introducing austerity measures towards the end of the electoral cycle: it decreases by roughly

\footnotetext{
${ }^{13}$ These approximated standard errors are calculated using the standard errors of the untransformed coefficients $b$ as $\mathrm{SE}_{\mathrm{OR}}$ $=\mathrm{OR} \times \mathrm{SE}_{b}$. The 95 per cent confidence intervals of the odds ratios can be calculated using the untransformed coefficients as $\mathrm{CI}_{\mathrm{OR}}=\exp \left(b \pm 1.96 \times \mathrm{SE}_{b}\right)$.
} 


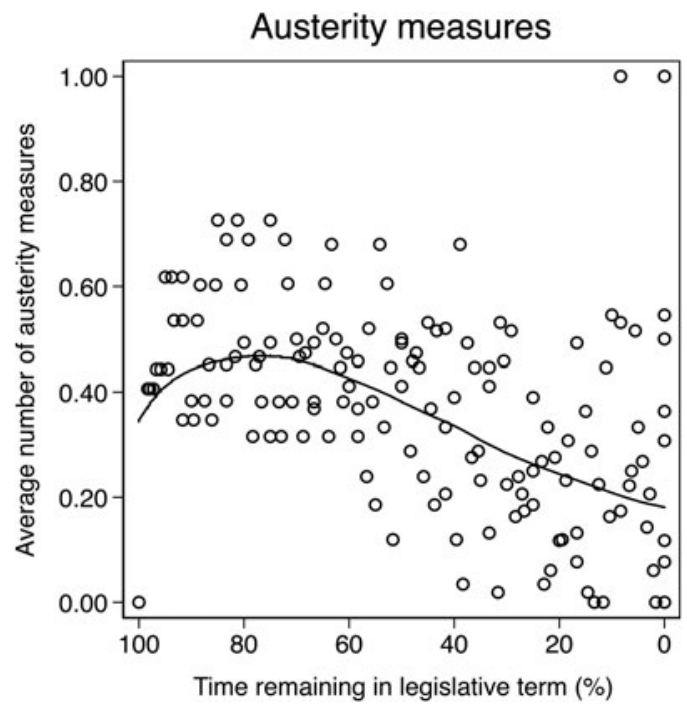

Figure 1. Average number of austerity reform measures by the percentage of time remaining in the legislative term across all cabinets in the sample

Note: Line represents the Lowess fitted curve; each dot indicates the mean number of austerity reform measures at a given time across all cabinets in the analysis.
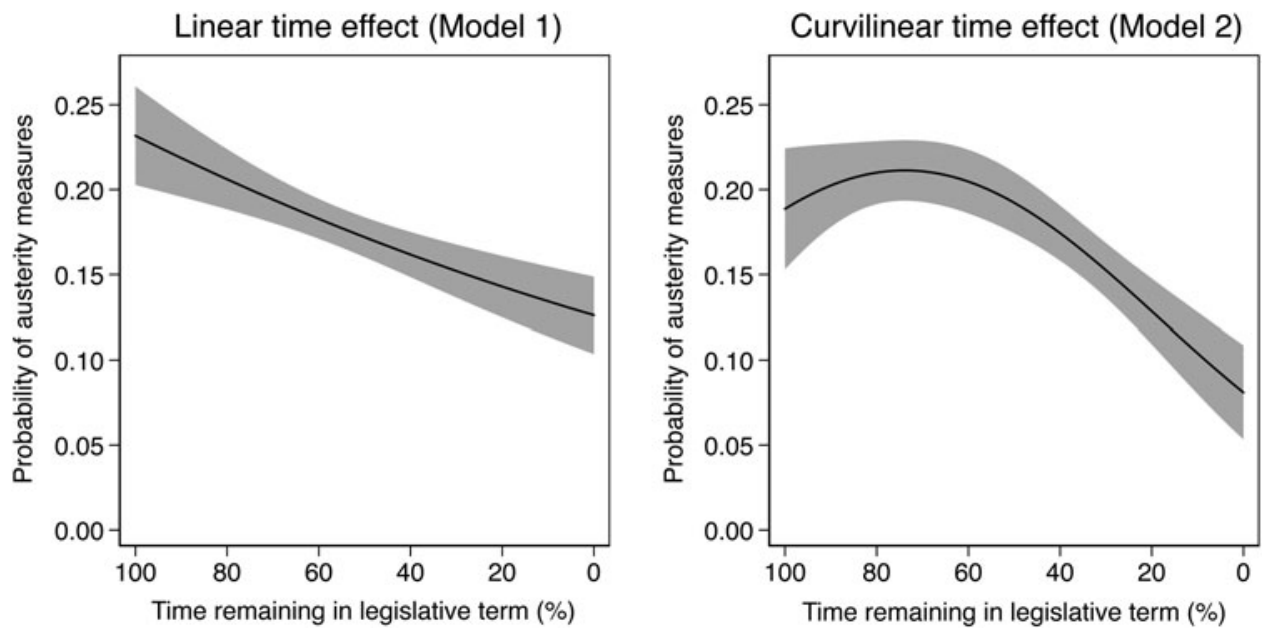

Figure 2. Effect of the percentage of time remaining in the legislative term on the probability of introducing austerity measures

Note: Predicted probabilities with 95 per cent confidence intervals obtained by holding other variables at their observed values using the margins command in Stata 15.0.

half over the course of the legislative term - from 23 per cent at the beginning to 13 per cent at the end according to the linear model (left panel), or from 19 to 8 per cent following the curvilinear model (right panel). Hence, governments are clearly more likely to introduce austerity reforms early in the legislative term.

The effects of our control variables are in line with common expectations. For example, the economics literature expects that increases in public debt should trigger the introduction of austerity measures to compensate for the debt. A coefficient of approximately 1.05 of the lagged change in public debt in Model 1 indicates that, holding all other factors constant, a 1 per 
cent increase in the public debt in the previous year increases the odds of an austerity reform by approximately 5 per cent $(95$ per cent CI: $1.015 ; 1.094)$. The signs of the estimated coefficients for the other macroeconomic control variables (lower than 1) suggest that governments are less likely to introduce austerity measures when GDP growth rates are high, and when the unemployment rate has increased. However, both coefficients are estimated with large standard errors and should thus be interpreted with caution. Lastly, the control variable for the introduction of reform measures other than austerity measures has a large effect in the models, which indicates that austerity and other measures often occur together and may be used to balance each other out. Excluding this control variable does not affect our substantive findings on the strategic timing of austerity measures.

We further investigate the conditions under which governments are more likely to time austerity measures opportunistically. We evaluate Hypotheses 2, 3 and 4 in Models 3 to 5 in Table 3, and present predicted probabilities in Figures 3 and 4. Taken separately, a change in the prime minister (Hypothesis 2) or cabinet type (Hypothesis 3) does not have a strong conditional effect on the likelihood that governments will time austerity measures early in the electoral cycle. Our analyses reveal that while the interaction between remaining time and prime minister change (Model 3), and between remaining time and government type (Model 4) are positive, as expected, these two-way interactions are not statistically significant.

However, the three-way interaction effect estimated in Model 5 supports our expectation in Hypothesis 4. Figure 4 illustrates the strategic timing of austerity measures according to the electoral cycle, accounting for new prime ministers and cabinet type. The change in predicted probabilities shows that the strategic timing of austerity measures is strongest among minimal winning cabinets with a new prime minister, where the slope across the legislative cycle is steepest. As we argue in Hypothesis 4, these cabinets can most credibly shift responsibility for introducing these measures to the preceding cabinet, and are able to act swiftly and introduce austerity measures early in the term. In line with this argument, we find that the probability of an austerity measure decreases much more towards the end of the electoral cycle among minimal winning cabinets with new prime ministers compared to minority and oversized coalition governments without leadership changes. ${ }^{14}$

Based on the results from Model 5, the predicted probability decreases by 34 per cent in the case of minimal winning cabinets with a new prime minister (95 per cent CI: -54.2 per cent, -14.0 per cent; see solid line in the right plot in Figure 4) from the beginning to the end of the legislative term. ${ }^{15}$ In contrast, the probability of introducing austerity measures decreases by only 10 per cent among minority and oversized cabinets without a new prime minister (95 per cent CI: -23.2 per cent, 2.8 per cent; see dashed line in the left plot in Figure 4). This constitutes a difference of about 24 per cent ( 95 per cent CI: -0.8 per cent; 48.8 per cent) between the changes in predicted probabilities of both scenarios. In other words, while the predicted probability of austerity measures drops towards the end of the legislative cycle among all cabinet types,

\footnotetext{
${ }^{14}$ As a change in prime minister can be accompanied by an ideological shift in the composition of the government, the conditional effect of leadership changes could be partially explained by preference shifts, rather than blame-avoidance strategies. For instance, a shift from a left-wing to a right-wing government could lead to an increase in early austerity measures. To test the robustness of our findings, we run additional analyses in which we examine the effect of the ideological position of the government on the probability of introducing austerity measures early in the legislative period (see Table A9 and Figure A4 in the Appendix). We find that governments that are further to the right than previous cabinets are indeed more likely to introduce austerity measures early in the legislative term compared to governments that are ideologically more to the left. However, our findings on leadership change are robust to the inclusion of government ideology. We provide a more detailed discussion of these findings in the Appendix.

${ }^{15}$ The predicted probability of introducing an austerity measure at the end of the legislative term $(0$ per cent of time remaining) is the same irrespective of the value of the two dummy variables ( $M W C$ and NEWPM), since the estimated models include cabinet fixed effects. All variables that vary only on the cabinet level (e.g., $M W C$ and NEWPM) enter the analyses only through the interaction between them and our TIME variable (percentage of time remaining in the legislative term) and are otherwise dropped from the analysis.
} 

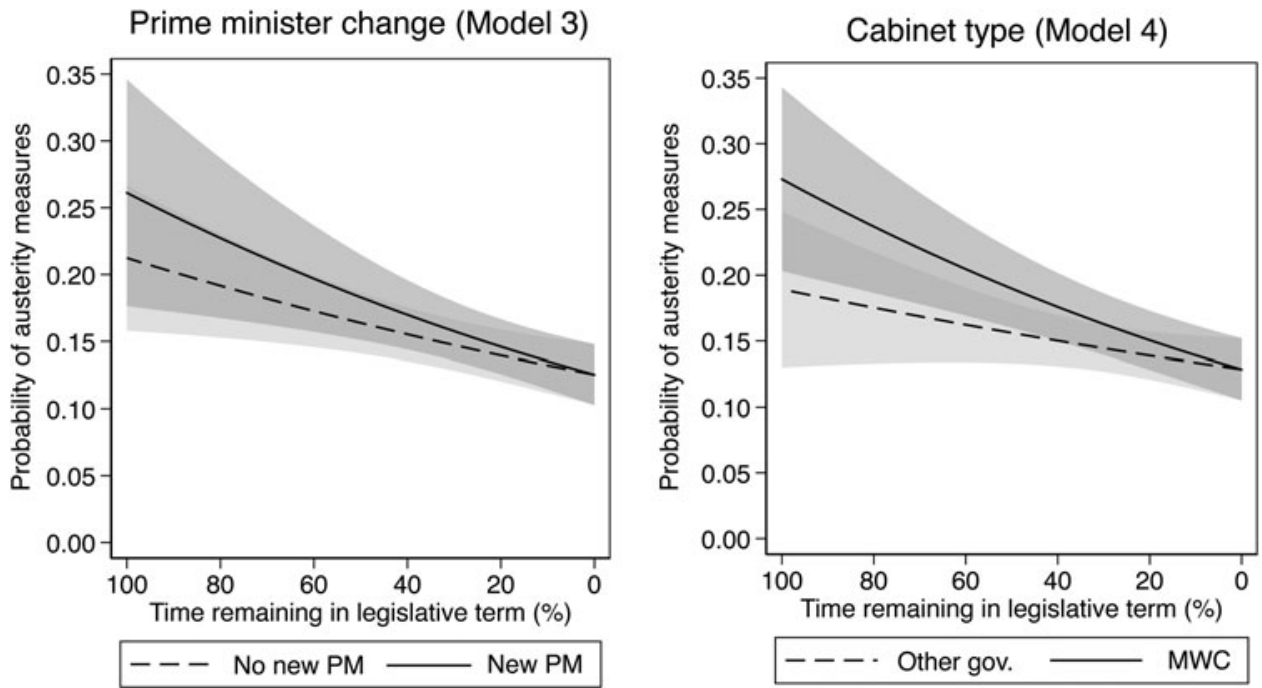

Figure 3. Conditional effect of electoral cycles by cabinets with new prime ministers and government type (Models 3 and 4)

Note: Predicted probabilities with 95 per cent confidence intervals obtained by holding other variables at their observed values using the margins command in Stata 15.0.
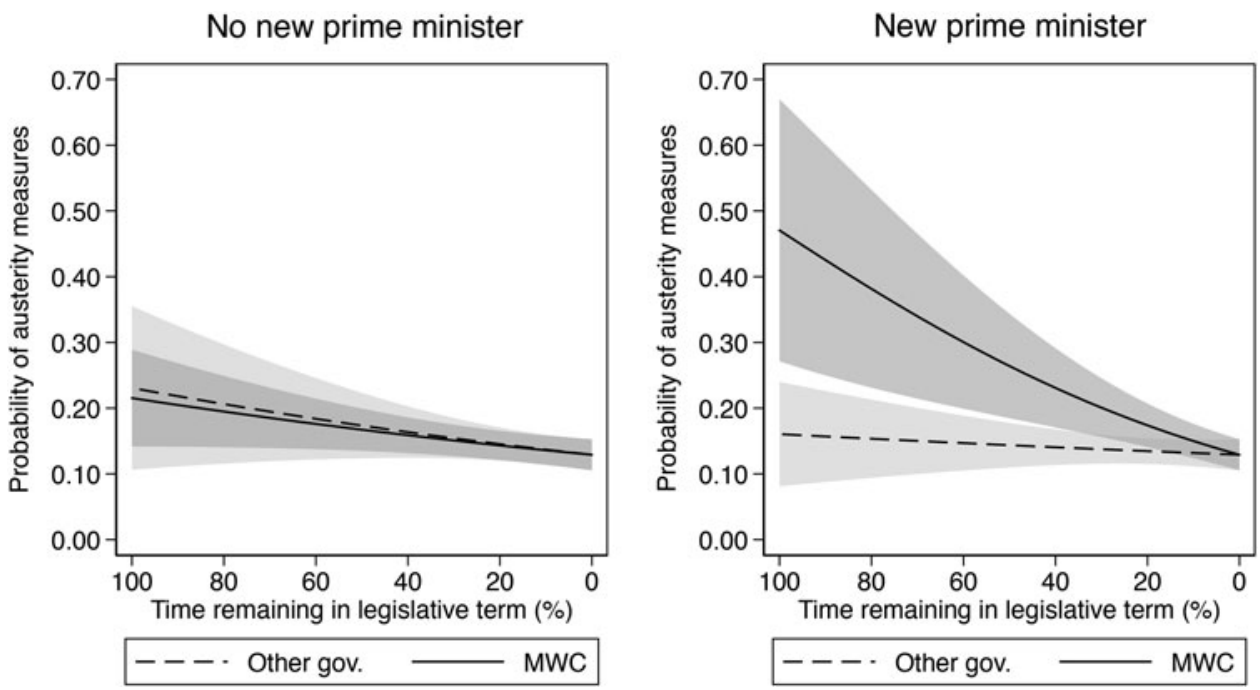

Figure 4. Three-way conditional effect of electoral cycles by cabinets with a new prime minister and government type (Model 5)

Note: Predicted probabilities with 95 per cent confidence intervals obtained by holding other variables at their observed values using the margins command in Stata 15.0.

the multivariate analysis indicates that this effect is stronger among minimal winning cabinets with a new prime minister. ${ }^{16}$

\footnotetext{
${ }^{16}$ We rerun Model 5 with a more restrictive alternative measure of change in government leadership, where we consider changes in the prime minister's party. We find substantively identical results, with similar effect sizes significant at the 0.1 significance level. Given the essentially identical effect sizes, we believe that the slightly larger confidence intervals are due to the lower variance in the PM party change variable. The results and replication files for this analysis are available upon request from the authors.
} 
In summary, we find clear support for Hypothesis 4, finding a three-way interaction between remaining time, prime minister change and government type. The fact that our empirical analyses support Hypothesis 4, as opposed to Hypotheses 2 and 3, which test the interactions between remaining time and the two cabinet features separately, suggests that governments need to fulfill both conditions in order to introduce austerity measures early on. It is not sufficient for governments to face a less complex bargaining environment, or to have the opportunity to shift blame; these two features seem to work in tandem for strategic cabinet decision making on austerity reform measures.

\section{Conclusion}

The timing of policy making and reforms has long been of interest in the political economy literature. Given the desire of incumbent governments to be re-elected and the recency bias of voters, researchers have suggested that governments strategically time the introduction of new policies to increase their electoral support in the run-up to elections. We contribute to the literature by applying the general logic of electoral cycles to the legislative realm. We investigate the strategic timing of austerity reform measures using a novel time-series cross-sectional dataset on substantive taxation and social reform measures introduced via laws and government decrees in thirteen Western European countries over a period of twenty years.

In contrast to the vast majority of previous work, which studies economic indicators to evaluate arguments about electoral cycles, we test the actions of political opportunism by focusing on reform measures, which are under direct government control. Instead of analyzing the number of all legislative acts, we take into account their content and concentrate on important reform measures, which are more visible to voters. Our focus on individual austerity reform measures as the unit of analysis rather than laws, which can include one or a package of many reform measures, ensures comparability across cases.

Our empirical results support the idea that political parties strategically time austerity reforms early in their term of office to maximize their electoral support. They have incentives to do so because of the voters' recency bias, and to shift responsibility for costly measures to previous governments, which they can credibly do when there is a leadership change in the government. However, only certain types of governments have the ability to act swiftly and use the short window of opportunity to introduce costly measures early on. We find support for the 'ability' and 'responsibility shifting' arguments, showing that minimal winning governments with a new prime minister are more likely to introduce austerity measures earlier in the electoral cycle.

These findings make a direct contribution to the literature on political electoral cycles and have important implications for our understanding of how governments in representative democracies structure their reform agenda and policy choices. Our findings highlight the importance of governments' ability and opportunity to strategically time policy decisions, and provide valuable insights for scholars interested in the role of government types and leadership change in policy making and government policy agendas.

These findings also have direct implications for voting behavior. Knowledge about what types of governments strategically time austerity measures should help voters understand when to predominantly rely on recent policy events and when to consider the whole legislative term in their economic voting decisions. In particular, our findings imply that only taking the government's recent policy output into account in the wake of elections might be misleading, especially for governments that are able to act swiftly and shift responsibility onto the previous government.

Our research sheds new light on the reform-making behavior of parties, which opens various avenues for future research. We have focused specifically on the dynamics and strategic timing of austerity reform measures, which impose direct monetary costs on voters. According to the political business and budget cycle literatures, in order to increase their electoral chances, governments should not only try to avoid negative signals, but should also send positive signals and 
directly benefit voters in the run-up to elections. Following this theoretical expectation, we hope our work will encourage future research to explore the strategic timing of expansionary reforms that directly increase the monetary benefits for voters (such as increases in social benefits), as well as the balance between austerity and expansionary measures.

Supplementary material. Data replication sets are available in Harvard Dataverse at: https://oi.org/10.7910/DVN/ MSIW8E and online appendices at: https://doi.org/10.1017/S0007123419000073.

Acknowledgements. The authors are grateful to the SFB 884 'Political Economy of Reforms' at the University of Mannheim and the FWF (grants I 1607-G11 and I 3793-G27) for financial support. We are very thankful to the anonymous reviewers and editors of the British Journal of Political Science for thorough and helpful constructive comments and to the participants of the research seminar at the Department of Government, University of Vienna, and discussants and participants at the APSA 2018 for valuable feedback on earlier drafts. We are particularly indebted to Sebastian Hartmann and Katharina Barié for their excellent research work as well as to all our research assistants at the University of Vienna and the University of Mannheim for their coding.

\section{References}

Alesina A, Cohen G and Roubini N (1993) Electoral business cycles in industrial democracies. European Journal of Political Economy 23 (1), 1-23.

Alt J and Lassen D (2006) Transparency, political polarization, and political budget cycles in OECD countries. American Journal of Political Science 50 (3), 530-550.

Armingeon K et al. (2015) Comparative Political Data Set 1960-2013. Bern: Institute of Political Science, University of Berne.

Beck N, Katz J and Tucker R (1998) Taking time seriously: time-series-cross-section analysis with a binary dependent variable. American Journal of Political Science 42 (4), 1260-1288.

Bickers K and Stein R (1996) The electoral dynamics of the federal pork barrel. American Journal of Political Science 40 (4), $1300-1326$.

Blais A and Nadeau R (1992) The electoral budget cycle. Public Choice 74 (4), 389-403.

Bunce V (2014) Do New Leaders Make a Difference? Executive Succession and Public Policy Under Capitalism and Socialism. Princeton, NJ: Princeton University Press.

Carrubba C and Volden C (2000) Coalitional politics and logrolling in legislative institutions. American Journal of Political Science 44 (2), 261-277.

Carter D and Signorino C (2010) Back to the future: modeling time dependence in binary data. Political Analysis 18 (3), 271-292.

Chang E (2008) Electoral incentives and budgetary spending: rethinking the role of political institutions. Journal of Politics 70 (4), 1086-1097.

Clark W (2002) Partisan and electoral motivations and the choice of monetary institutions under fully mobile capital. International Organization 56 (4), 725-749.

Clark W and Hallerberg M (2000) Mobile capital, domestic institutions, and electorally induced monetary and fiscal policy. American Political Science Review 94 (2), 323-346.

Clark W et al. (1998) International and domestic constraints on political business cycles in OECD economies. International Organization 52 (1), 87-120.

Crombez C (1996) Minority governments, minimal winning coalitions and surplus majorities in parliamentary systems. European Journal of Political Research 29 (1), 1-29.

De Haan J (2014) Democracy, elections and government budget deficits. German Economic Review 15 (1), 131-142.

De Haan J and Klomp J (2013) Conditional political budget cycles: a review of recent evidence. Public Choice 157 (3-4), 387-410.

Döring H and Manow P (2016) Parliaments and Governments Database (ParlGov): Information on Parties, Elections and Cabinets in Modern Democracies. Development version. Available at http://www.parlgov.org/ (accessed 13 April 2018).

Drazen A (2000) The political business cycle after 25 years. In Bernanke B and Rogoff K (eds), NBER Macroeconomic Annual 2000, Vol. 15. Cambridge, MA: MIT Press.

Drazen A (2001) Political Economy in Macroeconomics. Princeton, NJ: Princeton University Press.

Drazen A and Eslava M (2010) Electoral manipulation via voter-friendly spending: theory and evidence. Journal of Development Economics 92 (1), 39-52.

Duch R and Stevenson R (2008) The Economic Vote: How Political and Economic Institutions Condition Election Results. Cambridge: Cambridge University Press.

Economist Intelligence Unit (EIU) (1990) Country Report: Sweden, April 1990. London: Economist Intelligence Unit.

Fair R (1978) The effect of economic events on votes for president. Review of Economics and Statistics 60 (2), $159-173$.

Fiorina M (1981) Retrospective Voting in American National Elections. New Haven, CT: Yale University Press. 
Franzese R (2002) Macroeconomic Policies of Developed Countries. Cambridge: Cambridge University Press.

Ganghof S and Bräuninger T (2006) Government status and legislative behaviour: Partisan veto players in Australia, Denmark, Finland, and Germany. Party Politics 12 (4), 521-539.

Giger N and Nelson M (2011) The electoral consequences of welfare state retrenchment: blame avoidance or credit claiming in the era of permanent austerity? European Journal of Political Research 50 (1), 1-23.

Giger N and Nelson M (2013) The welfare state or the economy? Preferences, constituencies, and strategies for retrenchment. European Sociological Review 29 (5), 1083-1094.

Greene W (2004) The behaviour of the maximum likelihood estimator of limited dependent variable models in the presence of fixed effects. Econometrics Journal 7 (1), 98-119.

Hallerberg M, de Souza L and Clark W (2002) Political business cycles in EU accession countries. European Union Politics 3 (2), 231-250.

Hallerberg M and Scartascini C (2017) Explaining changes in tax burdens in Latin America: do politics trump economics? European Journal of Political Economy 48 (1), 162-179.

Healy A and Lenz G (2014) Substituting the end for the whole: why voters respond primarily to the election-year economy. American Journal of Political Science 58 (1), 31-47.

Heckelman J and Berument H (1998) Political business cycles and endogenous elections. Southern Economic Journal 64 (4), 987-1000.

Hellwig T and Samuels D (2007) Voting in open economies: the electoral consequences of globalization. Comparative Political Studies 40 (3), 283-306.

Hill S et al. (2013) How quickly we forget: the duration of persuasion effects from mass communication. Political Communication 30 (4), 521-547.

Hübscher E and Sattler T (2017) Fiscal consolidation under electoral risk. European Journal of Political Research 56 (1), 151-168.

Ito T (1990) The timing of elections and political business cycles in Japan. Journal of Asian Economics 1 (1), 35-156.

Ito T and Park J (1988) Political business cycles in the parliamentary system. Economics Letters 27 (3), $233-238$.

Jordà Ò and Taylor AM (2016) The time for austerity: estimating the average treatment effect of fiscal policy. Economic Journal 126 (590), 219-255.

Kahneman D and Tversky A (1986) Choices, values, and frames. In Smelser NJ and Gerstein DR (eds), Behavioral and Social Science. Fifty Years of Discovery. Washington, DC: National Academy Press, pp. 153-172.

Kayser M (2005) Who surfs, who manipulates? The determinants of opportunistic election timing and electorally motivated economic intervention. American Political Science Review 99 (1), 17-27.

Katz E (2001) Bias in conditional and unconditional fixed effects logit estimation. Political Analysis 9 (4), 379-384.

Klitgaard M and Elmelund-Præstekær C (2014) The partisanship of systemic retrenchment: tax policy and welfare reform in Denmark 1975-2008. European Political Science Review 6 (1), 1-19.

Klomp J and De Haan J (2013) Political budget cycles and election outcomes. Public Choice 157 (1), $245-267$.

König P and Wenzelburger G (2017) Honeymoon in the crisis: a comparative analysis of the strategic timing of austerity policies and their effect on government popularity in three countries. Comparative European Politics 15 (6), 991-1015.

Kovats L-Z (2014) Uncertainty and Decision-Making. How Legislation Cycles Unveil Inter-Institutional Power-Relations in the European Union. Dissertation, University of Potsdam.

Krause GA (2005) Electoral incentives, political business cycles and macroeconomic performance: empirical evidence from post-war US personal income growth. British Journal of Political Science 35 (1), 77-101.

Kriner D and Reeves A (2012) The influence of federal spending on presidential elections. American Political Science Review 106 (2), 348-366.

Lagona F and Padovano F (2008) The political legislation cycle. Public Choice 134 (3), 201-229.

Laver M and Schofield N (1998) Multiparty Government: The Politics of Coalition in Europe. Ann Arbor: University of Michigan Press.

Lewis-Beck M (1990) Economics \& Elections. The Major Western Democracies. Ann Arbor: University of Michigan Press.

MacKuen M, Erikson R and Stimson J (1992) Peasants or bankers? The American electorate and the US Economy. American Political Science Review 86 (3), 597-611.

MacRae C (1977) A political model of the business cycle. Journal of Political Economy 85 (2), 239-263.

Maravall JM (1997) Regimes, Politics, and Markets. Oxford: Oxford University Press.

Martin P and Philippon T (2017) Inspecting the mechanism: leverage and the great recession in the eurozone. American Economic Review 107 (7), 1904-1937.

McCallum B (1978) The political business cycle: an empirical test. Southern Economic Journal 44 (3), 504-515.

McGraw K (1990) Avoiding blame: an experimental investigation of political excuses and justifications. British Journal of Political Science 20 (1), 119-131.

Mink M and De Haan J (2006) Are there political budget cycles in the euro area? European Union Politics 7 (2), $191-211$.

Mueller D (2003) Public Choice III. Cambridge: Cambridge University Press.

Nordhaus W (1975) The political business cycle. Review of Economic Studies 42 (2), 169-190. 
Pacek A and Radcliff B (1995) The political economy of competitive elections in the developing world. American Journal of Political Science 39 (3), 745-759.

Persson T and Tabellini G (2000) Political Economics: Explaining Economic Policy. Cambridge, MA: MIT Press.

Pierson P (1996) The new politics of the welfare state. World Politics 48 (2), 143-179.

Powell G and Whitten G (1993) A cross-national analysis of economic voting: taking account of the political context. American Journal of Political Science 37 (2), 391-314.

Prichard W (2018) Electoral competitiveness, tax bargaining and political incentives in developing countries: evidence from political budget cycles affecting taxation. British Journal of Political Science 48, 427-457.

Rogoff K and Sibert A (1988) Elections and macroeconomic policy cycles. Review of Economic Studies 55 (1), 1-16.

Schacter DL (1996) Searching for Memory: The Brain, the Mind, and the Past. New York: Basic Books.

Schultz K (1995) The politics of the political business cycle. British Journal of Political Science 25 (1), 79-99.

Schumacher G, Vis B and Van Kersbergen K (2013) Political parties' welfare image, electoral punishment and welfare state retrenchment. Comparative European Politics 11 (1), 1-21.

Shi M and Svensson J (2006) Political budget cycles: do they differ across countries and why? Journal of Public Economics 90 (8-9), 1367-1389.

Shughart W and Tollison R (1985) Legislation and political business cycles. Kyklos 38 (1), 43-59.

Strobl D, Angelova M, Bäck H and Müller WC (2019) Replication Data for: Electoral Cycles in Government Policy Making: Strategic Timing of Austerity Reform Measures in Western Europe, https://doi.org/10.7910/DVN/MSIW8E, Harvard Dataverse, V1, UNF:6:ahl1FXowYU0R3inUClqScg== [fileUNF].

Stokes SC (1999) What do policy switches tell us about democracy? In Przeworski A, Stokes SC and Manin B (eds), Democracy, Accountability, and Representation. Cambridge: Cambridge University Press, pp. 98-130.

Strøm K, Müller WC and Bergman T (eds) (2008) Cabinets and Coalition Bargaining: The Democratic Life Cycle in Western Europe. Oxford: Oxford University Press.

Tsebelis G (1995) Decision making in political systems: veto players in presidentialism, parliamentarism, multicameralism and multipartyism. British Journal of Political Science 25 (3), 289-325.

Vis B (2009) Governments and unpopular social policy reform: biting the bullet or steering clear? European Journal of Political Research 48 (1), 31-57.

Weaver RK (1986) The politics of blame avoidance. Journal of Public Policy 6 (4), 371-398.

Wenzelburger G (2014) Blame avoidance, electoral punishment and the perceptions of risk. Journal of European Social Policy 24 (1), 80-91.

Wenzelburger G and Hörisch F (2016) Framing effects and comparative social policy reform: comparing blame avoidance evidence from two experiments. Journal of Comparative Policy Analysis: Research and Practice 18 (2), 157-175.

Wiese R (2014) What triggers reforms in OECD countries? Improved reform measurement and evidence from the healthcare sector. European Journal of Political Economy 34 (1), 332-352.

Willett T and Bananian K (1988) Legislation and political business cycles: comment. Kyklos 41 (3), 507-511.

Cite this article: Strobl D, Bäck H, Müller WC, Angelova M (2021). Electoral Cycles in Government Policy Making: Strategic Timing of Austerity Reform Measures in Western Europe. British Journal of Political Science 51, 331-352. https://doi.org/ $10.1017 /$ S0007123419000073 